\title{
Hydroponic cultivation of Physalis angulata L.: growth and production under nitrogen doses ${ }^{1}$
}

\author{
Romeu da Silva Leite ${ }^{2}$, Tamara Torres Tanan², \\ Marilza Neves do Nascimento ${ }^{2}$, Lenaldo Muniz de Oliveira², Pedro Alcantara da Silva Abreu ${ }^{2}$
}

\section{ABSTRACT}

The Physalis angulata L. species has attracted interest due to the production of compounds with pharmacological activity and its potential for fruiticulture. Given that it is a fast-growing and highly productive species, determining the most adequate nitrogen $(\mathrm{N})$ doses could contribute to higher crop yields. This study aimed at assessing the influence of $\mathrm{N}$ concentrations, in a hydroponic system, on the growth and production of $P$. angulata, as well as determining the critical $\mathrm{N}$ level in leaves. The experiment was conducted in individual pots with nutrient solutions, applying a completely randomized design and twelve replications, using five $\mathrm{N}$ doses (0 mg L-1, $56 \mathrm{mg} \mathrm{L}^{-1}, 112 \mathrm{mg} \mathrm{L}^{-1}, 168 \mathrm{mg} \mathrm{L}^{-1}$ and $224 \mathrm{mg} \mathrm{L}^{-1}$ ). Growth and production indices, amount of total $\mathrm{N}$ on leaves and stems and critical $\mathrm{N}$ levels were assessed. The increase of $\mathrm{N}$ doses in the nutrient solution influenced plant growth and fruit production, as well as the accumulation of total $\mathrm{N}$ in the leaves and stems. Based on the maximum economic yield, a dose of $162 \mathrm{mg} \mathrm{L}^{-1}$ of $\mathrm{N}$ is recommended for hydroponics, which provided a fruit yield of $7.27 \mathrm{~g} \mathrm{~m}^{-2}$ and critical total $\mathrm{N}$ level in leaves of $51.98 \mathrm{~g} \mathrm{~kg}^{-1}$.

KEYWORDS: Solanaceae; nitrogen fertilization; plant growth index.

\section{INTRODUCTION}

The Physalis angulata L. species (Solanaceae) stands out for its medicinal potential, since it contains compounds derived from simple vitanolids, denominated physalins, normally found in the leaves, roots and stems of the plant. Its fruits have attracted the interest of producers and consumers due to their sweetness and high nutraceutical value (Tomassini et al. 2000, Lorenzi \& Matos 2008).

Because of its promising potential, a large number of studies have been conducted with the

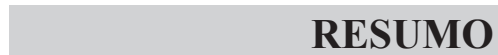

Cultivo hidropônico de Physalis angulata L.: crescimento e produção sob doses de nitrogênio

A espécie Physalis angulata L. tem se destacado devido à produção de compostos com atividade farmacológica e ao seu potencial para a fruticultura. Por apresentar crescimento rápido e grande produtividade, a definição de doses de nitrogênio $(\mathrm{N})$ mais adequadas pode contribuir para maiores rendimentos da cultura. Objetivou-se avaliar a influência de concentrações de N, em sistema hidropônico, sobre o crescimento e produção de plantas de $P$. angulata, bem como determinar o nível crítico de $\mathrm{N}$ nas folhas. $\mathrm{O}$ experimento foi conduzido em vasos individuais com soluções nutritivas, em delineamento inteiramente casualizado com doze repetições, utilizando-se cinco doses de $\mathrm{N}\left(0 \mathrm{mg} \mathrm{L}^{-1}, 56 \mathrm{mg} \mathrm{L}^{-1}\right.$, $\left.112 \mathrm{mg} \mathrm{L}^{-1}, 168 \mathrm{mg} \mathrm{L}^{-1} \mathrm{e} 224 \mathrm{mg} \mathrm{L}^{-1}\right)$. Foram avaliados os índices de crescimento e produção, a quantificação do $\mathrm{N}$ total nas folhas e caules e o nível crítico de N. O aumento das doses de N na solução nutritiva influenciou o crescimento das plantas e a produção de frutos, bem como o acúmulo de $\mathrm{N}$ total nas folhas e caules. Com base na máxima produtividade econômica, recomenda-se para o cultivo hidropônico a dose de $162 \mathrm{mg} \mathrm{L}^{-1}$ de $\mathrm{N}$, que proporcionou produtividade dos frutos de 7,27 $\mathrm{g} \mathrm{m}^{-2}$ e nível crítico de $\mathrm{N}$ total nas folhas de $51,98 \mathrm{~g} \mathrm{~kg}^{-1}$.

PALAVRAS-CHAVE: Solanaceae; fertilização nitrogenada; índice de crescimento de plantas.

species, primarily to identify and assess substances with possible medicinal value (Guimarães et al. 2009, Sá et al. 2011). However, just a few researches have investigated its cultivation or management, including Souza \& Amorim (2009), who assessed the growth and development of the species under water deficit, and Cruz et al. (2015), who evaluated the influence of phosphate fertilizer on its cultivation. Nevertheless, much needs to be studied to establish cash crops of the species, particularly in terms of mineral nutrition.

Mineral nutrition refers to the supply of nutrients to plants, aimed at increasing yields and

1. Manuscript received in Dec./2016 and accepted for publication in May/2017 (http://dx.doi.org/10.1590/1983-40632016v4744652).

2. Universidade Estadual de Feira de Santana, Departamento de Ciências Biológicas, Feira de Santana, BA, Brazil.

E-mails: leiteromeu@hotmail.com, tamara.tanan@yahoo.com.br, marilzaagro@hotmail.com, lenaldo.uefs@gmail.com, pedro_804@outlook.com. 
obtaining products with good nutrient quality and suitable traits for their use. However, the plants grown typically use less than half of the fertilizers applied, and the rest is leached to the groundwater, contributing to environmental pollution. One way to mitigate these effects is to grow crops in a protected environment, using techniques such as hydroponics. This system results in rapid plant growth and increased protection against diseases and pests, which are common in Solanaceae, in addition to greater control of $\mathrm{pH}$ and fertility, thereby increasing yield and reducing fertilizer costs (Paulus et al. 2012)

In hydroponic production systems, the composition and management of the nutrient solution are crucial elements that determine water and mineral availability to the crop during its growth cycle (Le Bot et al. 2001). Nitrogen is one of the macronutrients that most limits plant growth and development, making it essential for plants, with a direct effect on photoassimilate distribution between the vegetative and reproductive parts, prompting changes in the plant physiology and morphology, related to photosynthesis, root system enlargement, ionic nutrient uptake and cell development (Queiroga et al. 2007). The excess or deficiency of this nutrient is harmful to the plant, affecting its growth and production, and may result in significant losses.

As such, this study aimed at assessing the influence of nitrogen $(\mathrm{N})$ concentrations, in a hydroponic system, on the growth and production of $P$. angulata plants, as well as determining the critical leaf $\mathrm{N}$ level.

\section{MATERIAL AND METHODS}

The experiment was carried out between July and August 2015, at the Unidade Experimental Horto Florestal $\left(12^{\circ} 14^{\prime} \mathrm{S}, 38^{\circ} 58^{\prime} \mathrm{W}\right.$ and altitude of $\left.258 \mathrm{~m}\right)$ of the Universidade Estadual de Feira de Santana (UEFS), in Feira de Santana, Bahia state, Brazil.

Seedlings were produced using seeds obtained from plants grown at the UEFS. The seeds were planted at a depth of $2 \mathrm{~cm}$, in disposable paper cups filled with a mixture of commercial substrate $\left(\right.$ Plantamax $\left.{ }^{\circledR}\right)$ and sand (1:1). After seeding, the cups were kept in a greenhouse, with daily irrigation. At 15 days after seedling emergence, when they were approximately 3-4 $\mathrm{cm}$ high and bearing 2 pairs of leaves, they were transplanted to individual pots containing a nutrient solution and anchored on a
Styrofoam board placed directly onto the surface of the solution.

The experiment consisted of 60 polypropylene pots $(22 \mathrm{~cm}$ high $\mathrm{x} 25 \mathrm{~cm}$ top diameter $\mathrm{x} 18 \mathrm{~cm}$ bottom diameter), with a capacity of $7 \mathrm{~L}$, containing $6 \mathrm{~L}$ of nutrient solution. The pots were kept on a galvanized iron bench with $0.8 \mathrm{~m}$ spacing between rows and $0.2 \mathrm{~m}$ between plants. The nutrient solution was aerated for 15 minutes every three hours, during the experiment, using a compressor $(250 \mathrm{~W}$, with an air flow rate of $100 \mathrm{~L} \mathrm{~min}^{-1}$ ).

A completely randomized design, with five treatments, was used, consisting of $\mathrm{N}$ doses $\left(0 \mathrm{mg} \mathrm{L}^{-1}\right.$, $56 \mathrm{mg} \mathrm{L}^{-1}, 112 \mathrm{mg} \mathrm{L}^{-1}, 168 \mathrm{mg} \mathrm{L}^{-1}$ and $224 \mathrm{mg} \mathrm{L}^{-1}$ ) and twelve repetitions per treatment, with one pot and one plant per repetition. Sarruge's (1975) nutrient solution was used, modified to supply each $\mathrm{N}$ dose. During the experiment, the $\mathrm{pH}$ of the nutrient solution was maintained at a range between 5.5 and 6.5, electric conductivity was monitored periodically, and the solution was changed whenever the electric conductivity decreased by $20 \%$, when compared to the initial value.

Growth was assessed at 40 days after transplanting (DAT), using four randomly selected plants per treatment. The following characteristics were assessed: plant height $(\mathrm{cm})$, stem diameter $(\mathrm{mm})$ and ripe fruit production $\left(\mathrm{g} \mathrm{plant}^{-1}\right)$. Leaf area was measured by the leaf disk method, using a drill with known area to remove nine leaf disks per plant. The disks were packed in paper bags and placed in a forced air circulation oven at $60^{\circ} \mathrm{C}$, for $72 \mathrm{~h}$. Next, they were weighed separately using an analytical scale. The following equation was used to determine the leaf area: leaf area $=[($ dry leaf mass $(\mathrm{g})+$ dry disk mass $(\mathrm{g})] /[$ dry disk mass $(\mathrm{g})] \mathrm{x}$ disk area.

The fruits were collected at 40 DAT, when they were greenish-yellow and ripe for harvest. Estimated fruit yield was calculated by the following equation: yield $=$ plant production $(\mathrm{g}) \mathrm{x}$ area occupied per plant $\left(0.16 \mathrm{~m}^{2}\right)$. Next, the plant material was packed in paper bags and placed in a forced air circulation oven, to determine shoot dry mass.

Growth indices, such as leaf area ratio, leaf mass ratio, absolute growth rate and relative growth rate, were determined according to Cairo et al. (2008), and total $\mathrm{N}$ was calculated in dry leaf and stem matter, using the semi-Kjedahl method (Bataglia et al. 1983). The regression equation proposed by Cate $\&$ Nelson (1965) was used to establish the critical level of 
total $\mathrm{N}$. Thus, the $\mathrm{N}$ doses applied to the solution were related with leaf content and crop yield according to Faquin (2002). The critical level was estimated at $95 \%$ of maximum production.

The data obtained were submitted to analysis of variance and regression, and the equations of the characteristics assessed were adjusted as variables dependent on $\mathrm{N}$ concentration. Statistical analyses were conducted applying the Sisvar 4.1 software (Ferreira 2008).

\section{RESULTS AND DISCUSSION}

For shoot dry mass, the equation obtained exhibited $\mathrm{R}^{2}$ of 0.99 , showing an increase in this variable with a rise of the $\mathrm{N}$ concentration in the nutrient solution (Figure 1a). Wamser (2014) also observed quadratic responses to the increase of $\mathrm{N}$ in the nutrient solution for the accumulation of shoot dry mass in red pepper (Capsicum annuum L.) grown under concentrations of nitrogen and potassium. Increases in dry mass, as a function of $\mathrm{N}$ doses, are expected, given that this nutrient contributes to the vegetative growth of plants, acting primarily on budding rate, leaf expansion, final leaf size and stem lengthening.

The increased $\mathrm{N}$ concentration in the nutrient solution affected the leaf area of plants, with a linear tendency $\left(r^{2}=0.98\right)$. In the control treatment (without $\mathrm{N}$ supply), the leaf area was $2.41 \mathrm{~cm}^{2}$, while the value obtained at the highest $\mathrm{N}$ dose $\left(224 \mathrm{mg} \mathrm{L}^{-1}\right)$ was $5,332.11 \mathrm{~cm}^{2}$ (Figure 1b). It is known that increased leaf area or canopy photosynthesis results in a better use of solar energy, which is associated with the generation of photoassimilates and consequently greater shoot dry mass (Purquerio et al. 2007), as observed in the present study.

Plant height and stem diameter were influenced by the treatments used, with the best fit equation by the quadratic model ( $\mathrm{R}^{2}$ of 0.91 and 0.96 , respectively). Plant height increased up to a dose of $166.3 \mathrm{mg} \mathrm{L}^{-1}$ of $\mathrm{N}$, with a mean value of $93.9 \mathrm{~cm}$ (Figure 1c). Stem diameter showed a similar behavior, with a maximum value $(22.3 \mathrm{~mm})$ at an estimated dose of $172.0 \mathrm{mg} \mathrm{L}^{-1}$ of $\mathrm{N}$ (Figure 1d). The decline in plant size, due to the application of higher $\mathrm{N}$ doses, may indicate an
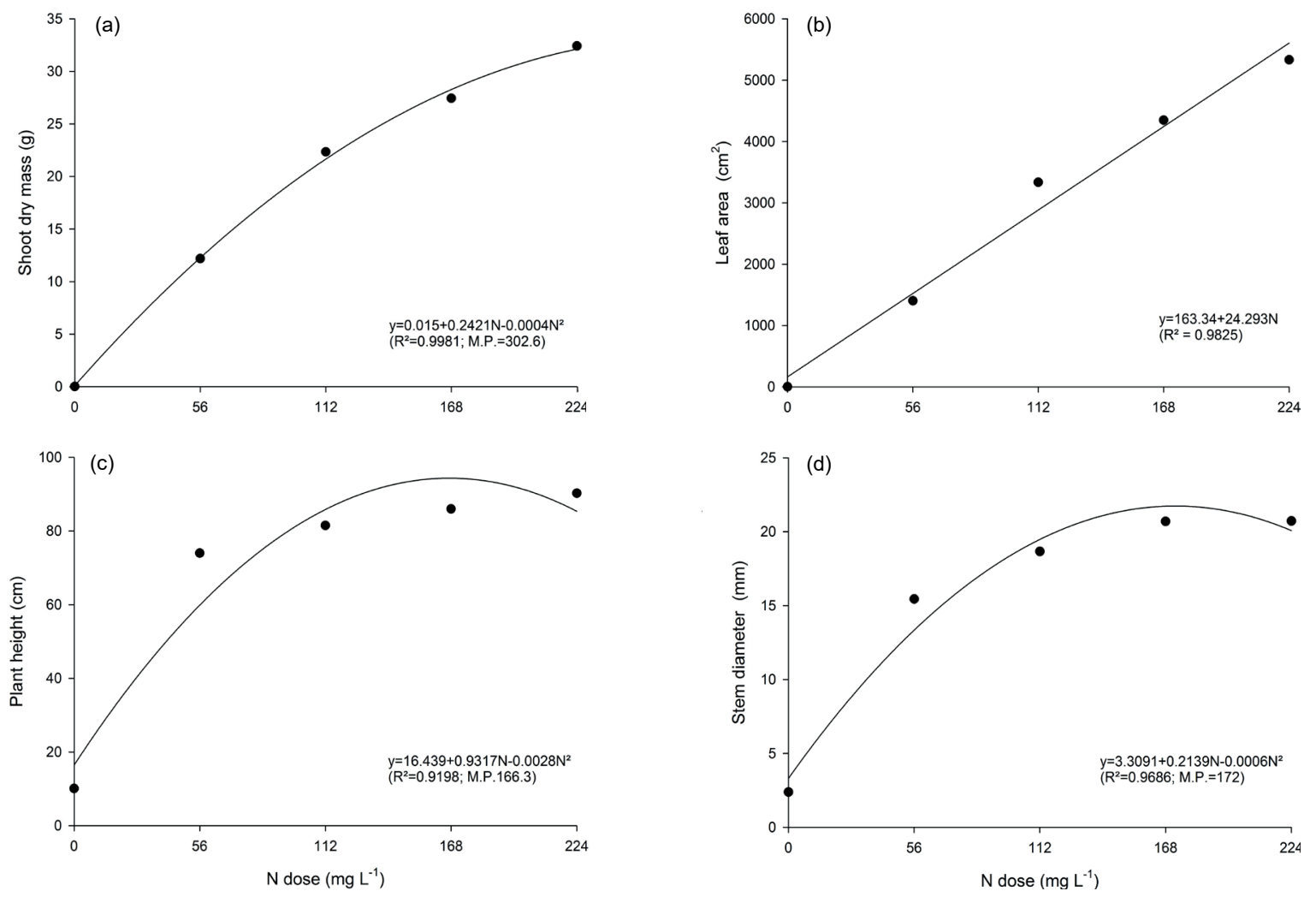

Figure 1. Shoot dry mass (a), leaf area (b), plant height (c) and stem diameter (d) of Physalis angulata plants, as a function of nitrogen concentrations in the nutrient solution. M.P.: maximum production. 
imbalance between other elements, thereby reducing growth (Souza \& Soratto 2006).

It is important to point out that hydroponics accelerated the phenological phases of $P$. angulata and that, at 40 DAT, the plant already bore ripe fruits, while, in a study carried out by Tanan (2015) with the same species in the field, only flower buds were observed at 40 DAT. Early vegetable production in hydroponic cultivation was also reported by Feltrim et al. (2005) and Bione et al. (2014), which may be explained by the easy absorption of the nutrient solution and decrease in the energy released for $\mathrm{N}$ assimilation.
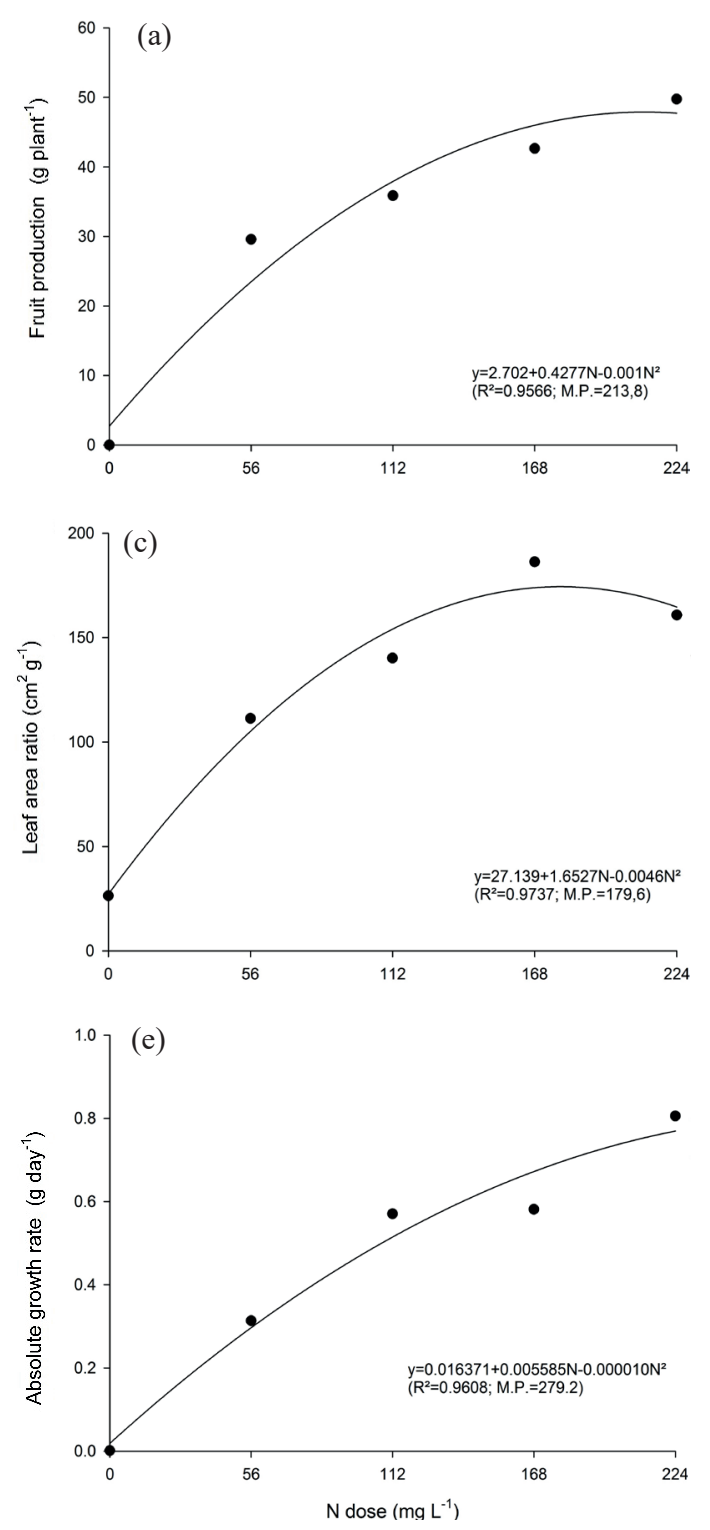

Fruit production exhibited a quadratic response $\left(\mathrm{R}^{2}=0.95\right)$, with a greater fruit mass $\left(48.4 \mathrm{~g} \mathrm{plant}^{-1}\right)$ at an estimated dose of $213.8 \mathrm{mg} \mathrm{L}^{-1}$ of N (Figure 2a). The estimated dose of $211.3 \mathrm{mg} \mathrm{L}^{-1}$ of $\mathrm{N}$ resulted in a greater yield increase of $7.66 \mathrm{~g} \mathrm{~m}^{-2}$ (Figure 2b). Increased fruit yield is a desirable trait, characterizing a species with significant crop potential and use of these fruits for fresh consumption and industrialization.

The leaf area ratio peaked at a concentration of $179.6 \mathrm{mg} \mathrm{L}^{-1}$ of $\mathrm{N}\left(\mathrm{R}^{2}=0.97\right)$, corresponding to $175.58 \mathrm{~cm}^{2} \mathrm{~g}^{-1}$ (Figure 2c), with a decline in plants submitted to $224 \mathrm{mg} \mathrm{L}^{-1}$ of $\mathrm{N}$. The leaf area ratio represents the leaf area available for photosynthesis
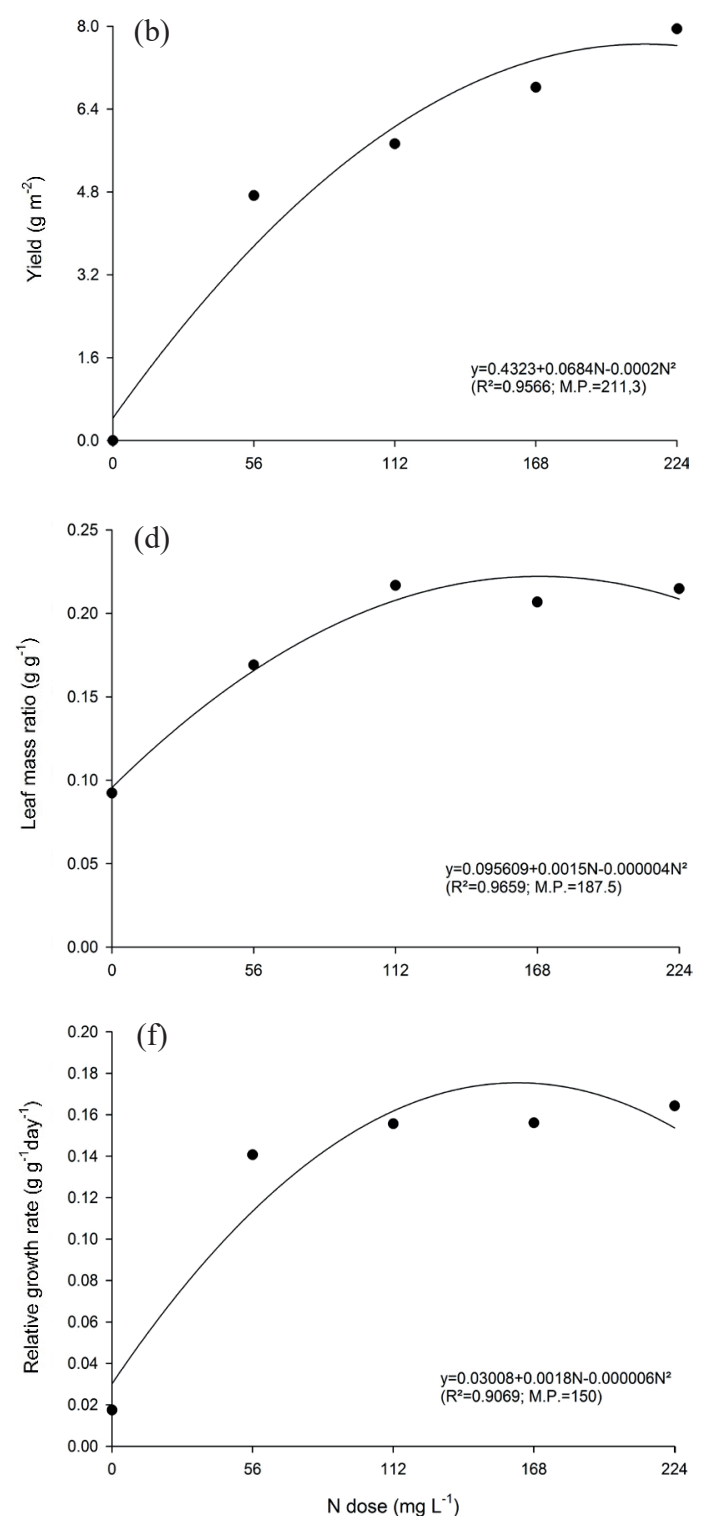

Figure 2. Fruit production (a), yield (b), leaf area ratio (c), leaf mass ratio (d), absolute growth rate (e) and relative growth rate (f) in Physalis angulata plants, as a function of nitrogen concentrations in the nutrient solution. M.P.: maximum production. 
and, according to Benincasa (2003), declines with plant growth because upper leaves shade their lower counterparts. This was not observed in the present study, given that the dosage that produced the greatest height and relative growth rate also resulted in a higher leaf area ratio. The leaf mass ratio is a physiological component that represents the ratio between the dry mass retained in the leaves and the dry mass accumulated in the entire plant, reflecting how much of what the plant invested in its production, via photosynthesis, remained in the leaf (Costa et al. 2006). The leaf mass ratio values behaved similarly to those of leaf area ratio, with a decline observed in plants submitted to the largest $\mathrm{N}$ dose applied $\left(\mathrm{R}^{2}=\right.$ $0.96)$ and the greatest retention of photosynthesized leaf material at a dose of $187.5 \mathrm{mg} \mathrm{L}^{-1}$ (Figure 2d).

The absolute growth rate, which represents the speed of plant growth, was influenced by $\mathrm{N}$ doses and exhibited quadratic behavior $\left(\mathrm{R}^{2}=0.96\right)$, with the highest value being $0.8 \mathrm{~g} \mathrm{day}^{-1}$, with a dose of $224 \mathrm{mg} \mathrm{L}^{-1}$ (Figure 2e). Cruz et al. (2015) reported a linear behavior for this variable, when assessing the influence of phosphorous on $P$. angulata growth, observing an absolute growth rate of $0.47 \mathrm{~g} \mathrm{day}^{-1}$ at the highest dose of $\mathrm{P}\left(64 \mathrm{mg} \mathrm{kg}^{-1}\right)$. The relative growth rate also displayed a quadratic response $\left(\mathrm{R}^{2}=0.90\right)$, with the highest value $\left(0.16 \mathrm{~g} \mathrm{~g}^{-1}\right.$ day $\left.^{-1}\right)$ occurring at an estimated dose of $150 \mathrm{mg} \mathrm{L}^{-1}$ of N (Figure 2f). The relative growth rate curve exhibited similar behavior to that of leaf area ratio and the morphological component of leaf area ratio.

There was a significant increase in total leaf and stem $\mathrm{N}$ content with an increase of $\mathrm{N}$ in the nutrient solution (Figure 3 ). The total leaf $\mathrm{N}$ content, regardless of treatment, was higher than that observed in the stem. The maximum leaf $\mathrm{N}$ content was $52.00 \mathrm{~g} \mathrm{~kg}^{-1}$, with a dose of $165.3 \mathrm{mg} \mathrm{L}^{-1}$ of $\mathrm{N}$ in the nutrient solution. With the exception of the control treatment, the leaf $\mathrm{N}$ content was within the suitable range for most Solanaceae, such as tomato (Fontes et al. 2004), potato (Coelho et al. 2010) and red pepper (Marcussi 2005).

The maximum total $\mathrm{N}$ content for the stem was $20.11 \mathrm{~g} \mathrm{~kg}^{-1}$, at a dose of $174.9 \mathrm{mg} \mathrm{L}^{-1}$. Similar results to those observed by Ianckievicz et al. (2013) were found. These authors assessed Physalis peruviana plants at different electrical conductivities in the nutrient solution, reporting that leaf $\mathrm{N}$ values ranged from $30.84 \mathrm{~g} \mathrm{~kg}^{-1}$ to $45.82 \mathrm{~g} \mathrm{~kg}^{-1}$ and stem values from $7.73 \mathrm{~g} \mathrm{~kg}^{-1}$ to $17.67 \mathrm{~g} \mathrm{~kg}^{-1}$.
Considering the maximum economic efficiency for the crop, the critical leaf total $\mathrm{N}$ value was $51.98 \mathrm{~g} \mathrm{~kg}^{-1}$, corresponding to $95 \%$ of maximum production $\left(7.27 \mathrm{~g} \mathrm{~m}^{-2}\right)$. This critical level was achieved with the supply of $162 \mathrm{mg} \mathrm{L}^{-1}$ of $\mathrm{N}$ in the nutrient medium, representing a $23.33 \%$ reduction
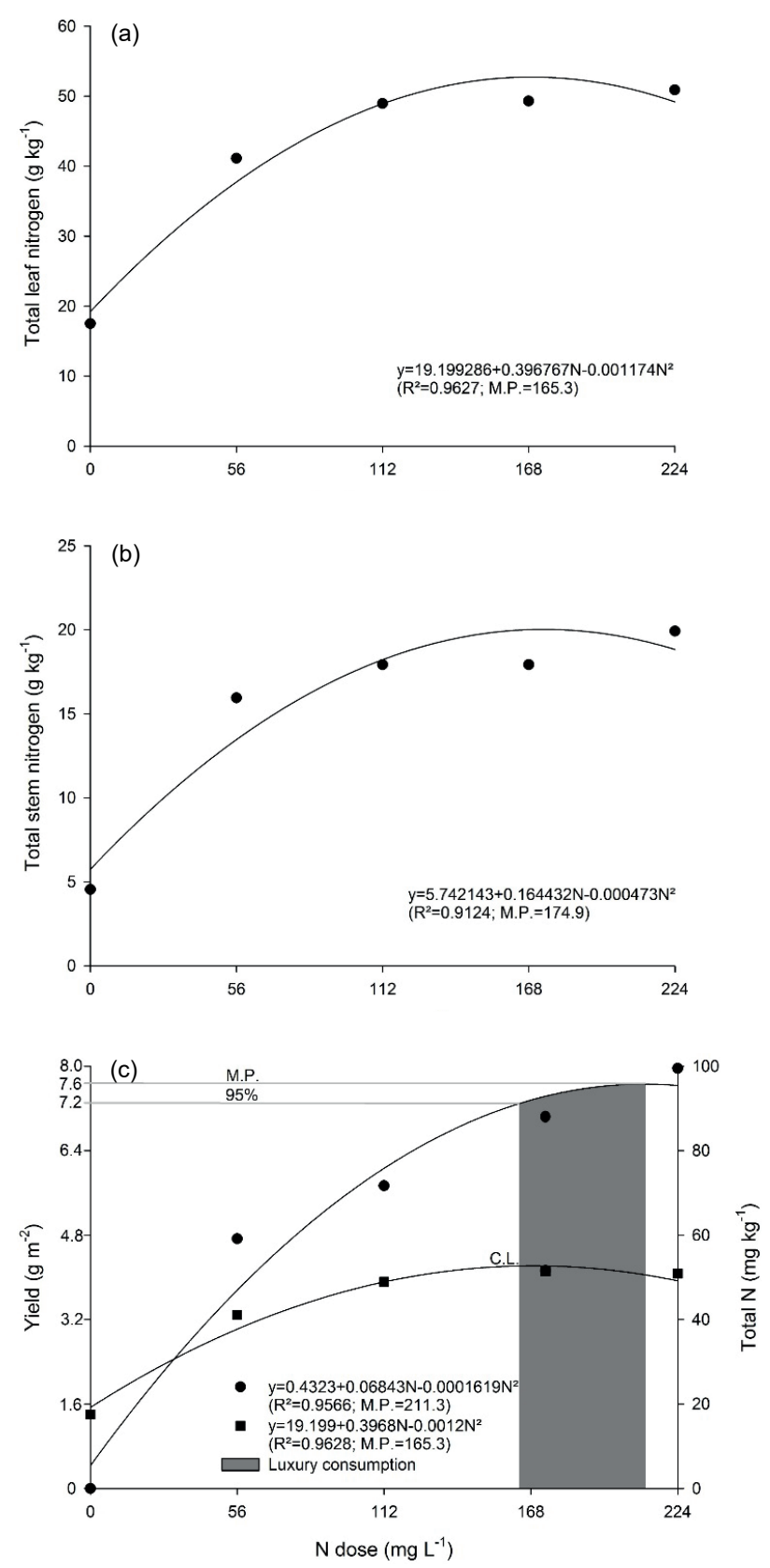

Figure 3. Total leaf (a) and stem (b) nitrogen content and relation among the $\mathrm{N}$ dose applied, yield $(\bullet)$ and leaf content ( $\square$ ) and the critical level (C.L.) for $95 \%$ of maximum production (M.P.) and luxury consumption (c) in Physalis angulata plants, as a function of $\mathrm{N}$ concentrations in the nutrient solution. 
(49.3 $\mathrm{mg} \mathrm{L}^{-1}$ ) in the amount of $\mathrm{N}$ responsible for maximum yield (Figure 3c). Thus, the dose responsible for the critical level value, in addition to ensuring a good production for $P$. angulata, results in a lower expenditure for the producer, given that $\mathrm{N}$ accounts for the best part of fertilizer costs and, along with excessive use, may contribute to environmental contamination (Silveira et al. 2012).

\section{CONCLUSION}

The increase in nitrogen doses in the nutrient solution influences plant growth, fruit production and accumulation of leaf and stem total $\mathrm{N}$ in Physalis angulata. Based on the maximum economic yield, a dose of $162 \mathrm{mg} \mathrm{L}^{-1}$ of $\mathrm{N}$ is recommended for its hydroponic cultivation, which resulted in a fruit yield of $7.27 \mathrm{~g} \mathrm{~m}^{-2}$ and a critical leaf total $\mathrm{N}$ level of $51.98 \mathrm{~g} \mathrm{~kg}^{-1}$.

\section{ACKNOWLEDGMENTS}

To the Universidade Estadual de Feira de Santana (UEFS) and Fundação de Amparo à Pesquisa do Estado da Bahia (Fapesb), for providing the necessary infrastructure, and the Conselho Nacional de Desenvolvimento Científico e Tecnológico (CNPq), for the scholarship awarded.

\section{REFERENCES}

BATAGLiA, O. C. et al. Métodos de análise química de plantas. Campinas: Instituto Agronômico, 1983. (Boletim técnico, 78).

BENINCASA, M. M. P. Análise de crescimento de plantas: noções básicas. Jaboticabal: Funep, 2003.

BIONE, M. A. A. et al. Crescimento e produção de manjericão em sistema hidropônico NFT sob salinidade. Revista Brasileira de Engenharia Agrícola e Ambiental, v. 18, n. 12, p. 1228-1234, 2014.

CAIRO, P. A. R. et al. Análise de crescimento de plantas. Vitória da Conquista: UESB, 2008.

CATE, R. B.; NELSON. L. A. A rapid method for correlation of soil analysis with plant response data. Washington, DC: North Carolina Agricultural Experimental Station, 1965.

COELHO, F. S. et al. Doses de nitrogênio associadas à produtividade de batata e índices do estado de nitrogênio na folha. Revista Brasileira de Ciência do Solo, v. 34, n. 4, p. 1175-1183, 2010.
COSTA, C. C. et al. Crescimento, produtividade e qualidade de raízes de rabanete cultivadas sob diferentes fontes e doses de adubos orgânicos. Horticultura Brasileira, v. 24, n. 1, p. 118-122, 2006.

CRUZ, J. L. et al. Influência da adubação fosfatada sobre o crescimento do camapu (Physalis angulata L.). Revista Brasileira de Plantas Medicinais, v. 17, n. 3, p. 360-366, 2015.

FAQUIN, V. Diagnose do estado nutricional das plantas. Lavras: Universidade Federal de Lavras, 2002.

FELTRIM, A. L. et al. Produção de alface americana em solo e em hidroponia, no inverno e verão, em Jaboticabal SP. Revista Brasileira de Engenharia Agrícola e Ambiental, v. 9, n. 4, p. 505-509, 2005.

FERREIRA, D. F. Sisvar: um programa para análises e ensino de estatística. Revista Cientifica Symposium, v. 6, n. 1, p. 36-41, 2008.

FONTES, P. C. R. et al. Produção e qualidade do tomate produzido em substrato, no campo e em ambiente protegido. Horticultura Brasileira, v. 22, n. 3, p. 614619, 2004.

GUIMARÃES, E. T. et al. Activity of physalins purified from Physalis angulata in vitro and in vivo models of cutaneous leishmaniasis. Journal of Antimicrobial Chemotherapy, v. 64, n. 1, p. 84-87, 2009.

IANCKIEVICZ, A. et al. Produção e desenvolvimento da cultura de Physalis L. submetida a diferentes níveis de condutividade elétrica da solução nutritiva. Ciência Rural, v. 43, n. 3, p. 438-444, 2013.

LE BOT, J. et al. Growth and nitrogen status of soilless tomato plants following nitrate withdrawal from the nutrient solution. Annals of Botany, v. 88, n. 3, p. 361$370,2001$.

LORENZI, H.; MATOS, M. Plantas medicinais no Brasil: nativas e exóticas cultivadas. 2. ed. Nova Odessa: Plantarum, 2008.

MARCUSSI, F. F. N. Uso da fertirrigação e teores de macronutrientes em planta de pimentão. Engenharia Agrícola, v. 25, n. 3, p. 642-650, 2005.

PAULUS, D. et al. Crescimento, consumo hídrico e composição mineral de alface cultivada em hidroponia com águas salinas. Revista Ceres, v. 59, n. 1, p. 110-117, 2012.

PURQUERIO, L. F. V. et al. Efeito da adubação nitrogenada de cobertura e do espaçamento sobre a produção de rúcula. Horticultura Brasileira, v. 25, n. 3, p. 464-470, 2007.

QUEIROGA, R. C. F. et al. Influência de doses de nitrogênio na produtividade e qualidade do melão Cantalupensis sob ambiente protegido. Horticultura Brasileira, v. 25, n. 4, p. 550-556, 2007. 
SÁ, M. S. et al. Antimalarial activity of physalins B, D, F e G. Journal of Natural Products, v. 74, n. 10, p. 22692272, 2011.

SARRUGE, J. R. Soluções nutritivas. Summa Phytopathologica, v. 1, n. 3, p. 231-233, 1975.

SILVEIRA, E. R. et al. Intensidade de pastejo e adubação nitrogenada na massa seca de aveia e produtividade do milho na integração lavoura-pecuária. Semina: Ciências Agrárias, v. 33, n. 4, p. 1323-1332, 2012.

SOUZA, E. F. C.; SORATTO, R. P. Efeito de fontes e doses de nitrogênio em cobertura, no milho safrinha, em plantio direto. Revista Brasileira de Milho e Sorgo, v. 5, n. 3, p. 395-405, 2006.

SOUZA, N. K. R.; AMORIM, S. M. C. de. Crescimento e desenvolvimento de Physalis angulata Lineu submetida ao déficit hídrico. Revista Acadêmica de Ciências Agrárias e Ambientais, v. 7, n. 1, p. 65-72, 2009.

TANAN, T. T. Fenologia e caracterização dos frutos de espécies de Physalis cultivadas no semiárido baiano. 2015. 58 f. Dissertação (Mestrado em Recursos Genéticos Vegetais) - Universidade Estadual de Feira de Santana, Feira de Santana, 2015.

TOMASSINI, T. C. B. et al. Gênero Physalis: uma revisão sobre vitaesteroides. Química Nova, v. 23. n. 1, p. 47-57, 2000.

WAMSER, A. F. Concentrações de nitrogênio e potássio na solução nutritiva do pimentão cultivado em substrato sem drenagem. 2014. 73 f. Tese (Doutorado em Agronomia) - Faculdade de Ciências Agrárias e Veterinárias, Universidade Estadual Paulista, Jaboticabal, 2014. 